\begin{tabular}{|c|c|c|}
\hline $\begin{array}{c}\text { AGROTECHIDLOGY } \\
\text { RESERRS }\end{array}$ & $\begin{array}{c}\text { Agrotech Res J, June } 2019,3(1): 1-7 \\
\text { AGROTECHNOLOGY RESEARCH } \\
\text { JOURNAL }\end{array}$ & $\begin{array}{l}\text { ISSN 2655-7924 (Print) } \\
\text { ISSN 2614-7416 (Online) } \\
\text { https://jurnal.uns.ac.id/arj } \\
\text { doi:10.20961/agrotechresj.v3i1.25792 }\end{array}$ \\
\hline
\end{tabular}

\title{
Effect of Type of Natural Substances Plant Growth Regulator on Nutmeg (Myristica Fragrans) Seedlings
}

\author{
Fitri Kurniati ${ }^{1 *}$, Elya Hartini ${ }^{2}$, Azhar Solehudin ${ }^{3}$ \\ ${ }^{1-3}$ Faculty of Agriculture, Universitas Siliwangi, Tasikmalaya, Indonesia
}

${ }^{*}$ Corresponding Author:

E-mail: fitri.kurniati61@gmail.com

Received 4 December 2018; Accepted 17 Januari 2019; Published 30 June 2019

\begin{abstract}
Nutmeg (Myristica fragrans Houtt) is an important spices in Indonesia. The advantages of nutmeg is essential oil content, the result of distillation which is for the spices industry, the manufacture of soaps, perfumes, cosmetics, have high economic value and are a source of foreign exchange to non oil \& gas, Indonesia is able to supply the needs of the market the world of up to $70 \%$ to $75 \%$. Generally, nutmeg in Indonesia use generative propagation which has the strong root system and long life, but the germination takes a long time. Using the natural plant growth regulators for germination can be used to accelerate growth. Natural PGR's can be extracted from some plants such shallot as a source of auxin, banana hump as a source of cytokinins, and bamboo shoots as a source of giberellin. The purpose of this study was to determine the types of natural PGR's that have good effect on the growth of nutmeg seedling. The experiment was carried out in Desa, Bugel, Kecamatan Ciawi Tasikmalaya with altitude at 600 meters above sea level, from June 2018 to September 2018. This study used Randomized Completely Block Design (RCBD) Method. The treatments were: $\mathrm{a} 0=$ control, $\mathrm{a}_{1}=$ shallot, $\mathrm{a}_{2}=$ bamboo shoot, $\mathrm{a}_{3}=$ banana hump, $\mathrm{a}_{4}=$ shallot + bamboo shoot, $a_{5}=$ shallot + , banana hump, $a_{6}=$ bamboo shoot + banana hump, $a_{7}=$ shallot + bamboo shoot + banana hump.The result showed that:1) type of natural substances plant growth regulator effected on various growth variable, 2) Combination of shallot bulb + bamboo shoot, or combination of shallot bulb + bamboo shoot and banana hump good effected on plant height, seedling diametre, number of leaf, leaf area, and shoot root ratio.
\end{abstract}

(c) 2019 Agrotechnology Research Journal

Keywords: Nutmeg; Type Natural PGR's; Bamboo Shoot; Banana Hump; Shallot

Cite This As: Kurniati F, Hartini E, Solehudin A. 2019. Effect of Type of Natural Substances Plant Growth Regulator (Pgr's) on Nutmeg (Myristica Fragrans) Seedlings. Agrotech Res $J$ 3(1): 1-7. https://doi.org/10.20961/agrotechresj.v3i1.25792

\section{PENDAHULUAN}

Pala (Myristica fragrans Houtt) merupakan komoditas rempah Indonesia yang penting, mempunyai keunggulan yaitu: kandungan minyak atsiri hasil penyulingan merupakan bahan baku industri obat, pembuatan sabun, parfum, kosmetik, sehingga mempunyai nilai ekonomis tinggi dan menjadi sumber devisa non migas (Bustaman 2008; Ruhnayat 2014). Produk pala Indonesia termasuk unggul karena memiliki aroma khas dan rendemen minyak tinggi, (Astanti et al. 2013).

Potensi pengembangan pala selanjutnya adalah meningkatkan produksi dengan memperluas wilayah

This is an open access article

Licensed under the Creative Commons Attribution International License CC-BY-SA 4.0 penanaman tanaman pala yang mencapai 3,600 ha, penggunaan bahan tanam yang unggul dan pendampingan petani tanaman pala (Direktorat Jenderal Perkebunan 2012). Hal ini berdampak terhadap bertambahnya kebutuhan benih.

Penanaman pala kebanyakan berasal dari biji. Tanaman yang dihasilkan biasanya mempunyai kelebihan dalam hal sistem perakarannya yang kuat, umur produksi lebih lama. Namun bibit asal biji juga mempunyai kelemahan yaitu waktu perkecambahan yang lama (2 sampai 3 bulan), pertumbuhan kecambah kadang tidak seragam dan pertumbuhan bibit yang lama pula, dan tingkat keberhasilan yang rendah sekitar 60 persen (Bustaman 2007; Nasir 2012). Biji pala termasuk jenis biji rekalsitran, yaitu benih yang cepat rusak (viabilitas menurun) apabila diturunkan kadar airnya, dan tidak tahan disimpan pada suhu dan kelembapan rendah (Yuniarti dan Rustam 2011). 
Dalam proses perkecambahan, zat pengatur tumbuh (ZPT) mempunyai peran penting, namun seringkali dalam pasokannya di bawah optimal terbatas (Gardner et al. 2008. Upaya untuk menunjang pertumbuhan tanaman yang dikendaki perlu ditambahan ZPT eksogen (Nurlaeni dan Imam 2015 dalam Pramita Laksitarahmi Isrianto 2017).

Nurlaeni dan Surya (2015), penggunaan ZPT eksogen alami merupakan alternatif yang mudah diperoleh, relatif murah dan aman digunakan. Dikatakan pula oleh Lindung (2014), bahwa ada berbagai jenis atau bahan tanaman yang merupakan sumber ZPT, seperti bawang merah sebagai sumber auksin, rebung bambu sebagai sumber giberelin, dan bonggol pisang serta sebagai sumber sitokinin,. Hasil penelitian Dea (2009), menunjukkan bahwa ekstrak rebung yang dianggap sebagai sumber giberelin memberikan pengaruh baik terhadap pertumbuhan bibit semai sengon.

Giberelin merupakan ZPT yang berpengaruh terhadap pembesaran tanaman, kemampuan giberelin untuk meningkatkan pertumbuhan tanaman lebih kuat dibandingkan dengan auksin apabila diberikan secara tunggal. Peran lain dari giberelin adalah dalam perkecambahan, terutama dalam pemecahan dormansi dengan cara mengaktifkan enzim-enzim yang berperan dalam memecah cadangan makanan dalam biji seperti amilase, protease, dan lipase. Bahan tersebut akan memberikan energi bagi perkembangan embrio diantaranya radikula yang akan mendobrak endosperm, kulit biji atau kulit buah yang biasanya menjadi faktor pembatas perkecambahan. Ini merupakan isyarat bahwa dormansi biji segera pecah dan biji segera berkecambah (Wareing dan Phillips 1981). Salisbury dan Ross (1995), juga menyatakan bahwa giberelin memacu pemanjangan sel di ujung tajuk dan memacu pertumbuhan sel karena giberelin berperan dalam meningkatkan hidrolisis pati dan sukrosa menjadi glukosa serta meningkatkan plastisitas dinding sel.

Sitokinin merupakan salah satu ZPT yang berperan dalam pembelahan sel. Peran sitokinin ini biasanya bekerja bersama-sama dengan auksin untuk menstimulasi pembelahan sel dan mempengaruhi lintasan diferensiasi (Abidin 1993). Gardner, Pearce dan Mitchell (2008), mengatakan bahwa ZPT bekerja secara sinergi dalam memunculkan suatu respons tanaman. Menurut Warner, Motyka Stranad dan Schmulling (2001) dalam Arif, Murniati dan Ardian (2016), sitokinin bila bekerjasama dengan auksin memiliki peran penting pada pembelahan sel dan diferensiasi jaringan tertentu dalam pembentukan tunas pucuk dan pertumbuhan akar. Juga dikatakan Lindung (2014), bahwa sitokinin bersama dengan auksin dan giberellin merangsang pembelahan sel tanaman.

Penelitian tentang bahan ZPT alami memberikan pengrauh yang berbeda-beda, antara lain terhadap pertumbuhan bibit kemiri sunan (Reutealis Trisperma) (Blanco) Airy Shaw) (Kurniati et al. 2015). Hasilnya menunjukkan bahwa rebung bambu konsentrasi $30 \mathrm{ml} / \mathrm{L}$ dan bonggol pisang $40 \mathrm{ml} / \mathrm{L}$ menghasilkan bibit tanaman kemiri sunan yang lebih tinggi. Pada penelitian lain oleh Kurniati et al. (2017) menunjukkan bahwa aplikasi berbagai bahan zat pengatur tumbuh alami memberikan pengaruh terhadap daya kecambah tinggi benih umur 30 hari setelah semai, 37 hari setelah semai, 44 hari setelah semai, 51 hari setelah semai, jumlah daun 37 har setelah semai dan jumlah daun 51 hari setelah semai pada benih kemiri Sunan (Reutealis trisperma (Blanco) Airy Shaw. Selanjutnya penelitian pada labu madu (Cucurbita moschata Durch) oleh Fitri Kurniati et al. (2017), menunjukkkan bahwa labu madu memberikan respons yang sama terhadap semua perlakuan ekstrak bahan ZPT alami berbagai dosis pada parameter tinggi tanaman, jumlah daun, bobot kering tanaman, bobot buah per butir, panjang buah, dan diameter buah, tetapi memberikan respons berbeda pada parameter luas daun dan bobot buah per tanaman. Luas daun terbesar terdapat pada pemberian ekstrak bonggol pisang $300 \mathrm{ml}$ $(7.119,77 \mathrm{~cm} 2)$ dan campuran (bawang merah + rebung bambu + bonggol pisang) $300 \mathrm{ml}(6.978,53)$. Bobot buah terbesar terdapat pada rebung bambu $300 \mathrm{ml}(388.62 \mathrm{~g})$ dan bonggol pisang $300 \mathrm{ml}$ (347.64 g).

Hasil yang bervariasi tersebut perlu ditelusuri lebih lanjut. Menurut Davies (1995) dalam Siregar et al. (2015), zat pengatur tumbuh tidak bekerja sendiri-sendiri melainkan saling berinteraksi satu dengan yang lainnya, oleh karena itu tujuan penelitian ini adalah mengetahui satu jenis atau kombinasi bahan zat pengatur tumbuh memberikan pengaruh yang baik terhadap pertumbuhan bibit pala (Myristica fragrans Hout).

\section{METODE PENELITIAN}

Percobaan dilaksanakan di Desa Bugel Kecamatan Ciawi Kabupaten Tasikmalaya dengan ketinggian tempat $600 \mathrm{~m}$ dpl di atas permukaan laut, pada bulan Mei sampai dengan Agustus 2018.Percobaan menggunakan Rancangan Acak Kelompok, dengan perlakuan jenis bahan zat pengatur tumbuh alami yaitu : $\mathrm{a} 0=$ kontrol (tanpa pemberian ZPT), $\mathrm{a} 1=$ bawang merah, a2= rebung bamboo, a3= bonggol pisang, a4= bawang merah + rebung, a5= bawang merah + bonggol pisang, $a 6=$ rebung + bonggol pisang, $a 7=$ bawang merah + rebung + bonggol pisang, Perlakuan diulang 4 kali sehingga terdapat 32 petak. Untuk melihat pengaruh perlakuan dilakukan Uji Fisher dan untuk mengetahui perlakuan yang berbeda diuji lanjut menggunakan Uji jarak Berganda Duncan pada taraf 5\%.

\section{Pelaksanaan Percobaan}

Bahan perlakuan yang terdiri dari bawang merah, rebung bambu, bonggol pisang, masing masing sebanyak $1 \mathrm{~kg}$ diekstrak dengan cara dihaluskan dengan menggunakan blender. Setelah halus kemudian ditambahkan M-bio sebanyak $30 \mathrm{ml}$ dan gula sebanyak $100 \mathrm{~g}$ serta diencerkan dengan air sampai volume $1 \mathrm{~L}$. Selanjutnya bahan tersebut difermentasi selama 10 hari. Ketika akan digunakan dibuat suspensi dari bahan tersebut dengan konsentrasi $60 \mathrm{ml} / \mathrm{L}$ Perlakuan 
diberikan untuk perendaman benih selama 24 jam. Selanjutnya perlakuan diberikan pada benih setiap minggu satu kali dengan volume $200 \mathrm{ml}$ per benih, dimulai sejak umur 7 hari setelah tanam sampai umur 42 hari setelah tanam.

Media persemaian berupa serbuk gergaji yang sudah lapuk dicampur dengan pupuk kandang dengan perbandingan 1 : 1 . Media persemaian tersebut ditempatkan pada baki plastik.Media tanam untuk pembibitan menggunakan campuran tanah dengan pupuk kandang dengan perbandingan 2:1. Media tanam dimasukkan pada polibag yang disusun pada lahan yang diberi naungan paranet.

\section{HASIL DAN PEMBAHASAN}

Analisis zat pengatur tumbuh pada bahan ZPT alami yang dilakukan oleh Indonesian Center For Biodiversity And Biotechnologi (ICBB) dapat dilihat pada Tabel 1. Hasil analisis pada berbagai bahan ZPT alami tersebut, terlihat bahwa kandungan ZPT yang terdapat pada setiap bahan yang dianalisis memiliki kandungan yang bervariasi. Berdasarkan analisis statistik, perlakuan jenis bahan zat pengatur tumbuh alami tidak berpengaruh terhadap daya kecambah namun berpengaruh terhadap tinggi tanaman, diameter batang, jumlah daun, luas daun, dan nisbah pupus akar.

\section{Daya Kecambah}

Tabel 2 menunjukkan bahwa pemberian bahan ZPT alami tidak memberikan pengaruh berbeda terhadap daya kecambah pala pada umur 30 dan 45 hari setelah tanam (HST). Namun terdapat kecenderungan bahwa kombinasi bawang merah dengan bonggol pisang lebih tinggi daripada yang lainnya dengan rata-rata daya kecambah umur 45 HST mencapai 85 persen, sedangkan terendah terdapat pada kontrol 77 persen.

Benih pala mampu berkecambah dengan baik apabila benih yang ditanam dihasilkan dari buah yang matang secara fisiologis, artinya kandungan material yang ada di dalam biji atau benih terpenuhi secara sempurna (Sunanto 1993). Menurut Kusumo (1990), bahwa salah satu cara perlakuan menggunakan ZPT adalah dengan cara merendam benih, perendaman ini memungkinkan benih mengalami imbibisi sehingga kadar air benih setelah perendaman akan meningkat dan menstimulir perkecambahan.

Menurut Marfirani (2014) Salah satu tumbuhan yang dianggap sebagai sumber zat pengatur tumbuh alami adalah bawang merah (Allium cepa L.) karena bawang merah memiliki kandungan hormon pertumbuhan berupa hormon auksin, sehingga dapat memacu pertumbuhan benih. Dalam proses perkecambahan selain pengaruh kandungan auksin yang terdapat pada bawang merah, kandungan sitokinin juga dapat membantu dalam proses perkecambahan seperti yang dikemukakan oleh Abidin (1986) dalam Anggari (2008), sitokinin berfungsi untuk mempengaruhi pertumbuhan dan diferensiasi akar, mendorong pembelahan sel dan pertumbuhan secara umum, mendorong perkecambahan dan menunda penuaan.

\section{Tinggi Benih}

Pemberian ZPT alami menunjukkan pengaruh terhadap tinggi tanaman umur 14, 28, 42 dan 56 hari setelah tanam (HST) (Tabel 3). Pada umur 56 HST, bawang merah + rebung bambu + bonggol pisang dan bawang merah + bonggol pisang memberikan pengaruh yang lebih baik dibandingkan perlakuan lainnya. Dalam menunjang pertumbuhan dan perkembangan tanaman, zat pengatur tumbuh tidak berkerja secara sendiri sendiri melainkan saling berinteraksi antara satu dengan yang lainya seperti yang dikemukakan oleh Davies (1995) dalam Siregar et al. (2015).

ZPT yang diberikan secara kombinasi memberikan pengaruh yang paling baik. Kandungan yang terdapat dalam setiap bahan ZPT alami seperti auksin yang banyak terdapat pada bawang merah, giberelin pada rebung bambu serta sitokinin dari bonggol pisang mampu menunjang proses pertumbuhan tinggi tanaman. Setiap zat pengatur tumbuh memiliki fungsi yang berbeda, seperti auksin berperan dalam mendorong pemanjangan sel hingga terjadinya pertumbuhan tinggi tanaman. mendefernsiasi jaringan xilem dan floem sehingga mendorong pembentukan akar (Siregar, dkk., 2015).

Tabel 1. Hasil Analisis Bahan Zat Pengatur Tumbuh Alam

\begin{tabular}{llcccc}
\hline \multirow{2}{*}{ No } & Parameter & Satuan & \multicolumn{3}{c}{ Hasil Analisis } \\
\cline { 4 - 5 } & & & Bonggol Pisang & Rebung Bambu & Bawang Merah \\
\hline 1 & Auksin & & & \\
& IAA & ppm & 147,25 & 125,72 & 156,01 \\
2 & Sitokinin & & & 122,34 \\
& Zietin & ppm & 123,44 & 104,73 & 140,11 \\
& Kinetin & ppm & 139,65 & 128,98 & 230,67 \\
\hline
\end{tabular}


Tabel 2. Pengaruh jenis bahan zat pengatur tumbuh alami terhadap daya kecambah.

\begin{tabular}{|c|c|c|}
\hline \multirow{2}{*}{ Perlakuan } & \multicolumn{2}{|c|}{ Daya Kecambah (\%) } \\
\hline & $30 \mathrm{HST}$ & $45 \mathrm{HST}$ \\
\hline $\mathrm{a}_{0}=$ kontrol & $31,25 a$ & $77,50 \mathrm{a}$ \\
\hline$a_{1}=$ bawang merah & $33,75 \mathrm{a}$ & $83,75 a$ \\
\hline $\mathrm{a}_{2}=$ rebung bambu & $32,50 \mathrm{a}$ & $78,75 a$ \\
\hline$a_{3}=$ bonggol pisang & $31,25 \mathrm{a}$ & $81,25 a$ \\
\hline$a_{4}=$ bawang merah + rebung bambu & $36,25 \mathrm{a}$ & $83,75 a$ \\
\hline$a_{5}=$ bawang merah + bonggol pisang & $35,00 \mathrm{a}$ & $85,00 \mathrm{a}$ \\
\hline $\mathrm{a}_{6}=$ rebung bambu + bonggol pisang & $33,75 \mathrm{a}$ & $82,50 \mathrm{a}$ \\
\hline$a_{7}=$ bawang merah + rebung bambu + bonggol pisang & $35,00 \mathrm{a}$ & $80,00 \mathrm{a}$ \\
\hline
\end{tabular}

Keterangan: Angka rata-rata pada kolom ditandai dengan huruf sama, menunjukkan tidak berbeda nyata berdasarkan Uji Fisher.

Tabel 3. Pengaruh jenis bahan zat pengatur tumbuh alami terhadap tinggi benih pala

\begin{tabular}{lllcc}
\hline \multirow{2}{*}{\multicolumn{1}{c}{ Perlakuan }} & \multicolumn{3}{c}{ Tinggi Tanaman $(\mathrm{cm})$} \\
\cline { 2 - 5 } & $14 \mathrm{HST}$ & $28 \mathrm{HST}$ & $42 \mathrm{HST}$ & $56 \mathrm{HST}$ \\
\hline $\mathrm{a}_{0}=$ kontrol & $3,13 \mathrm{~A}$ & $6,23 \mathrm{~A}$ & $9,76 \mathrm{a}$ & $13,64 \mathrm{a}$ \\
$\mathrm{a}_{1}=$ bawang merah & $4,60 \mathrm{Bc}$ & $8,73 \mathrm{Cd}$ & $12,04 \mathrm{~b}$ & $14,90 \mathrm{ab}$ \\
$\mathrm{a}_{2}=$ rebung bambu & $4,09 \mathrm{~B}$ & $6,96 \mathrm{~A}$ & $9,95 \mathrm{a}$ & $13,72 \mathrm{a}$ \\
$\mathrm{a}_{3}=$ bonggol pisang & $4,56 \mathrm{Bc}$ & $8,45 \mathrm{~B}$ & $12,44 \mathrm{bc}$ & $14,92 \mathrm{ab}$ \\
$\mathrm{a}_{4}=$ bawang merah + rebung bambu & $5,75 \mathrm{D}$ & $9,45 \mathrm{D}$ & $13,75 \mathrm{de}$ & $16,42 \mathrm{~cd}$ \\
$\mathrm{a}_{5}=$ bawang merah + bonggol pisang & $4,85 \mathrm{C}$ & $9,96 \mathrm{E}$ & $14,93 \mathrm{ef}$ & $17,03 \mathrm{de}$ \\
$\mathrm{a}_{6}=$ rebung bambu + bonggol pisang & $4,56 \mathrm{Bc}$ & $8,70 \mathrm{Bc}$ & $13,44 \mathrm{~cd}$ & $15,76 \mathrm{bc}$ \\
a7 $=$ bawang merah + rebung bambu & $6,26 \mathrm{D}$ & $11,36 \mathrm{E}$ & $16,03 \mathrm{f}$ & $17,74 \mathrm{e}$ \\
bonggol pisang & & & & \\
\hline
\end{tabular}

Keterangan: Angka rata-rata yang ditandai dengan huruf sama pada kolom menunjukkan tidak berbeda nyata menurut Uji Jarak Berganda Duncan pada taraf 5\%.

ZPT yang diberikan secara kombinasi memberikan pengaruh yang paling baik. Kandungan yang terdapat dalam setiap bahan ZPT alami seperti auksin yang banyak terdapat pada bawang merah, giberelin pada rebung bambu serta sitokinin dari bonggol pisang mampu menunjang proses pertumbuhan tinggi tanaman. Setiap zat pengatur tumbuh memiliki fungsi yang berbeda, seperti auksin berperan dalam mendorong pemanjangan sel hingga terjadinya pertumbuhan tinggi tanaman. mendefernsiasi jaringan xilem dan floem sehingga mendorong pembentukan akar (Siregar, dkk., 2015).Sementara itu menurut Sari et al. (2012) rebung bambu mengandung gilberelin yang merangsang pembelahan sel dan merangsang aktivitas enzim proteinase dan amilase yang berperan dalam proses perkecambahan, serta sitokinin pada bonggol pisang merangsang pembelahan sel, pembesaran pada batang, menghambat dominasi apikal serta mempercepat pertumbuhan memanjang. Menurut Maretza (2009), pertumbuhan tinggi tanaman dipengaruhi oleh hormon sitokinin yang terdapat di dalam bonggol pisang, sitokinin akan merangsang pembelahan sel melalui peningkatan laju sintesis protein.

\section{Diameter batang}

Pemberian ZPT alami bawah merah, rebung bambu, dan bonggol pisang memberikan pengaruh terhadap diameter batang pala pada umur 14,28, 42, dan 56 HST (Tabel 4). Pada umur 14 HST perlakuan bawang merah dan rebung bambu memberikan pengaruh yang paling baik terhadap diameter batang dengan nilai rata-rata 2,73 mm. Pada umur 28 HST perlakuan bawang merah, rebung bambu dan bonggol pisang memberikan pengaruh yang baik dibandingkan perlakuan lainnya. Pada umur 42 hari setelah tanam perlakuan kombinasi bawang merah, rebung bambu, dan bonggol pisang memberikan pengaruh baik.

Faktor yang mempengaruhi pembesaran tanaman yaitu auksin dan giberelin. Mekanisme kerja auksin yaitu mempengaruhi pelenturan dinding sel, sehingga air masuk secara osmosis dan memacu pemanjangan sel selanjutnya ada kerjasama antara auksin dan gilberelin yang memacu perkembangan jaringan pembuluh dan mendorong pembelahan sel sehingga mendorong pembesaran batang (Rusmin et al. 2011). 
Tabel 4. Pengaruh jenis zat pengatur tumbuh alami terhadap diameter batang $(\mathrm{mm})$

\begin{tabular}{lcccc}
\hline \multirow{2}{*}{\multicolumn{1}{c}{ Perlakuan }} & \multicolumn{4}{c}{ Diameter batang (mm) } \\
\cline { 2 - 5 } & $14 \mathrm{HST}$ & $28 \mathrm{HST}$ & $42 \mathrm{HST}$ & $56 \mathrm{HST}$ \\
\hline $\mathrm{a}_{0}=$ kontrol & $2,36 \mathrm{a}$ & $2,64 \mathrm{~A}$ & $2,86 \mathrm{~A}$ & $3,12 \mathrm{~A}$ \\
$\mathrm{a}_{1}=$ bawang merah & $2,57 \mathrm{bc}$ & $2,88 \mathrm{Bc}$ & $3,13 \mathrm{~B}$ & $3,23 \mathrm{Ab}$ \\
$\mathrm{a}_{2}=$ rebung bambu & $2,47 \mathrm{ab}$ & $2,78 \mathrm{Ab}$ & $3,05 \mathrm{~B}$ & $3,27 \mathrm{Ab}$ \\
$\mathrm{a}_{3}=$ bonggol pisang & $2,54 \mathrm{bc}$ & $2,97 \mathrm{C}$ & $3,12 \mathrm{~B}$ & $3,29 \mathrm{~B}$ \\
$\mathrm{a}_{4}=$ bawang merah + rebung bambu & $2,69 \mathrm{~cd}$ & $3,01 \mathrm{C}$ & $3,18 \mathrm{~B}$ & $3,45 \mathrm{D}$ \\
$\mathrm{a}_{5}=$ bawang merah + bonggol pisang & $2,57 \mathrm{bc}$ & $2,93 \mathrm{C}$ & $3,10 \mathrm{~B}$ & $3,43 \mathrm{Cd}$ \\
$\mathrm{a}_{6}=$ rebung bambu + bonggol pisang & $2,54 \mathrm{bc}$ & $2,90 \mathrm{Bc}$ & $3,11 \mathrm{~B}$ & $3,37 \mathrm{Bcd}$ \\
$\mathrm{a}_{7}=$ bawang merah + rebung bambu + bonggol & $2,73 \mathrm{~d}$ & $2,89 \mathrm{Bc}$ & $3,12 \mathrm{~B}$ & $3,40 \mathrm{Cd}$ \\
pisang & & &
\end{tabular}

Keterangan: Angka rata-rata yang ditandai dengan huruf yang sama pada kolom menunjukkan tidak berbeda nyata menurut Uji Jarak Berganda Duncan pada taraf 5\%.

\section{Jumlah Daun}

Pemberian ZPT alami bawah merah, rebung bambu, dan bonggol pisang memberikan pengaruh terhadap jumlah daun pada umur 14, 28, 42 dan 56 HST (Tabel 5). Pada umur 28 dan 42 HST perlakuan kombinasi bawang merah, rebung bambu dan bonggol pisang, memberikan pengaruh yang baik dibandingkan pada perlakuan yang lainnya. Pada umur 56 HST perlakuan bawang merah + rebung bamboo serta bawang merah, rebung bambu + bonggol pisang memberikan pengaruh yang lebih baik dibandingkan perlakuan lainnya. Sementara itu, jumlah daun yang paling kecil ditunjukan oleh kontrol. Zat pengatur tumbuh berperan aktif dalam menunjang pertumbuhan dan perkembangan tanaman serta saling berinteraksi. Zat pengatur tumbuh alami yang paling berperan dalam penambahan jumlah daun yaitu auksin yang banyak terdapat pada bawang merah seperti yang dikemukakan Zainal Abidin (1993) auksin memiliki fungsi dalam pemanjangan sel, pertumbuhan akar, fototrofisme, geotrofisme, partenocarpi, apical dominan, pembentukan khalus dan respirasi. Penelitian Siregar (2015) bahwa penambahan ekstrak bawang merah pada tanaman gaharu secara tidak langsung mempengaruhi penambahan jumlah daun, semakin tinggi tanaman maka jumlah daun semakin meningkat.

\section{Luas Daun}

Pada umur 56 HST pemberian ZPT alami bawang merah + rebung bambu + bonggol pisang memberikan pengaruh baik terhadap luas daun pala, seperti (Tabel 6). Pada umur 56 hari setelah tanam, perlakuan bawang merah + rebung bambu serta bawang merah + rebung bambu + bonggol pisang memberikan luas yang lebih baik dibandingkan pada perlakuan lainnya. Luas daun terkecil ditunjukkan oleh kontrol (tanpa pemberian ZPT). Kandungan ZPT yang mempengaruhi pertumbuhan luas daun yaitu auksin yang banyak terdapat dalam bawang merah dan giberelin pada rebung bambu.Menurut penelitian Ichsanudin (2014), bahwa perlakuan ekstrak umbi bawang merah terhadap bibit pepaya dengan konsentrasi $15 \mathrm{ml} / \mathrm{L}$ memberikan hasil tertinggi dibandingkan konsentrasi lainnya pada parameter kecepatan berkecambah, daya kecambah.

\section{Nisbah Pupus Akar}

Pemberian ZPT alami bawang merah + bonggol pisang + rebung bambu memberikan pengaruh yang nyata terhadap nisbah pupus akar dibandingkan perlakuan kontrol, bawang merah saja dan rebung bambu saja. Hal ini menunjukkan bahwa zat pengatur tumbuh tidak berkerja sendiri tetapi sinergi antara auksin, giberelin dan sitokinin. Seperti dikatakan Gardner, Pearce dan Mitchell (2008), bahwa ZPT bekerja secara sinergi dalam memunculkan suatu respons tanaman. Menurut Warner, Motyka Stranad dan Schmulling (2001) dalam Arif et al. (2016), sitokinin bila bekerja sama dengan auksin memiliki peran penting pada pembelahan sel dan diferensiasi jaringan tertentu dalam pembentukan tunas pucuk dan pertumbuhan akar. Juga dikatakan Lindung (2014), bahwa sitokinin bersama dengan auksin dan giberellin merangsang pembelahan sel tanaman. Sementara itu menurut Zainal Abidin (1993) bahwa permulaan terbentuknya akar tidak hanya dipengaruhi oleh auksin saja tetapi oleh sitokinin dan giberelin.

Menurut Lizawati et al. 2014 nisbah pupus akar mencerminkan pembagian hasil fotosintat dalam pertumbuhan tanaman. Nisbah pupus akar yang bernilai lebih dari satu menunjukkan pertumbuhan tanaman lebih ke arah pupus, sedangkan nisbah pupus atau akar yang bernilai kurang dari satu menunjukkan pertumbuhan tanaman lebih ke arah akar. Menurut Tyasmoro dan Barunawati (2017) semakin besar pertumbuhan organ vegetatif yang berfungsi sebagai penghasil asimilat (source) akan meningkatkan pertumbuhan organ pemakai (sink) yang akhirnya akan memberikan hasil yang semakin besar pula, namun jika tanaman tidak mampu membentuk asimilat yang cukup maka dapat terjadi kompetisi antara organ vegetatif dan generatif. Dalam hal ini pertumbuhan tanaman pala lebih ke arah pupus sehingga berat kering bagian atas tanaman menjadi meningkat daripada bagian akarnya. 
Tabel 5. Pengaruh jenis zat pengatur tumbuh alami terhadap jumlah daun (helai).

\begin{tabular}{lccc}
\hline \multicolumn{1}{c}{ Perlakuan } & \multicolumn{3}{c}{ Jumlah Daun $(\mathrm{cm})$} \\
\cline { 2 - 4 } & $28 \mathrm{HST}$ & $42 \mathrm{HST}$ & $56 \mathrm{HST}$ \\
\hline $\mathrm{a}_{0}=$ kontrol & $1,13 \mathrm{a}$ & $1,80 \mathrm{a}$ & $2,45 \mathrm{a}$ \\
$\mathrm{a}_{1}=$ bawang merah & $1,18 \mathrm{a}$ & $1,80 \mathrm{a}$ & $2,58 \mathrm{a}$ \\
$\mathrm{a}_{2}=$ rebung bambu & $1,23 \mathrm{a}$ & $1,93 \mathrm{abc}$ & $2,50 \mathrm{a}$ \\
$\mathrm{a}_{3}=$ bonggol pisang & $1,20 \mathrm{a}$ & $1,88 \mathrm{ab}$ & $2,53 \mathrm{a}$ \\
$\mathrm{a}_{4}=$ bawang merah + rebung bambu & $1,48 \mathrm{~b}$ & $2,23 \mathrm{c}$ & $3,03 \mathrm{~b}$ \\
$\mathrm{a}_{5}=$ bawang merah + bonggol pisang & $1,15 \mathrm{a}$ & $2,15 \mathrm{bc}$ & $2,80 \mathrm{~b}$ \\
$\mathrm{a}_{6}=$ rebung bambu + bonggol pisang & $1,13 \mathrm{a}$ & $2,15 \mathrm{bc}$ & $2,68 \mathrm{a}$ \\
$\mathrm{a}_{7}=$ bawang merah + rebung bambu + bonggol pisang & $1,23 \mathrm{~b}$ & $2,13 \mathrm{bc}$ & $3,08 \mathrm{~b}$ \\
\hline
\end{tabular}

Keterangan: Angka rata-rata yang ditandai dengan huruf yang sama pada kolom menunjukkan tidak berbeda nyata menurut Uji Jarak Berganda Duncan pada taraf 5\%.

Tabel 6. Pengaruh jenis bahan zat pengatur tumbuh alami terhadap luas daun.

\begin{tabular}{ll}
\hline \multicolumn{1}{c}{ Perlakuan } & \multicolumn{1}{c}{ Luas Daun (cm) } \\
\cline { 2 - 2 } $\mathrm{a}_{0}=$ kontrol & \multicolumn{1}{c}{$56 \mathrm{HST}$} \\
$\mathrm{a}_{1}=$ bawang merah & $283,88 \mathrm{a}$ \\
$\mathrm{a}_{2}=$ rebung bambu & $318,09 \mathrm{a}$ \\
$\mathrm{a}_{3}=$ bonggol pisang & $315,79 \mathrm{a}$ \\
$\mathrm{a}_{4}=$ bawang merah + rebung bambu & $344,74 \mathrm{ab}$ \\
$\mathrm{a}_{5}=$ bawang merah + bonggol pisang & $465,79 \mathrm{c}$ \\
$\mathrm{a}_{6}=$ rebung bambu + bonggol pisang & $354,93 \mathrm{ab}$ \\
$\mathrm{a}_{7}=$ bawang merah + rebung bambu +bonggol pisang & $358,55 \mathrm{ab}$ \\
\hline
\end{tabular}

Keterangan: Angka rata-rata yang ditandai dengan huruf yang sama pada kolom menunjukkan tidak berbeda nyata menurut Uji Jarak Berganda Duncan pada taraf $5 \%$.

Tabel 7. Pengaruh jenis bahan zat pengatur tumbuh alami terhadap nisbah pupus akar

\begin{tabular}{lc}
\hline \multicolumn{1}{c}{ Perlakuan } & Nisbah Pupus Akar $(\mathrm{cm})$ \\
\cline { 2 - 2 } $\mathrm{a}_{0}=$ kontrol & $56 \mathrm{HST}$ \\
$\mathrm{a}_{1}=$ bawang merah & $1,08 \mathrm{a}$ \\
$\mathrm{a}_{2}=$ rebung bambu & $1,22 \mathrm{a}$ \\
$\mathrm{a}_{3}=$ bonggol pisang & $1,12 \mathrm{a}$ \\
$\mathrm{a}_{4}=$ bawang merah + rebung bambu & $1,23 \mathrm{a}$ \\
$\mathrm{a}_{5}=$ bawang merah + bonggol pisang & $1,64 \mathrm{~B}$ \\
$\mathrm{a}_{6}=$ rebung bambu + bonggol pisang & $1,45 \mathrm{Ab}$ \\
$\mathrm{a}_{7}=$ bawang merah + rebung bambu + bonggol pisang & $1,25 \mathrm{~A}$ \\
\hline
\end{tabular}

Keterangan: Angka rata-rata yang ditandai dengan huruf yang sama pada kolom menunjukkan tidak berbeda nyata menurut Uji Jarak Berganda Duncan pada taraf $5 \%$.

\section{KESIMPULAN DAN SARAN}

\section{Kesimpulan}

1. Jenis bahan ZPT alami berpengaruh baik terhadap berbagai variabel pertumbuhan bibit pala.

2. Kombinasi bahan ZPT alami bawang merah dan rebung bambu serta kombinasi bawang merah, rebung bambu dan bonggol pisang berpengaruh baik terhadap parameter tinggi tanaman, diameter batang, jumlah daun, luas daun dan nisbah pupus akar.

\section{Saran}

1. Pada pembibitan tanaman pala dapat menggunakan ZPT alami yang dikombinasikan antara bawang merah dan rebung bambu atau bawang merah, rebung bambu dan bonggol pisang.

2. Melakukan penelitian lain menggunakan jenis bahan ZPT yang sama pada tanaman yang berbeda.

\section{DAFTAR PUSTAKA}

Abidin Z. 1993. Dasar-dasar pengetahuan tentang Zat pengatur tumbuh. Penerbit Angkasa. Bandung. 
Ruhnayat A. 2014. Teknologi budidaya pala. Balai Penelitian Tanaman Rempah dan Obat. Balai Penelitian dan Pengembangan Pertanian.

Arif M, Murniati, Ardian. 2016. Uji beberapa zat pengatur tumbuh alami terhadap pertumbuhan bibit karet (Hevea brasiliensis Muell Arg) stum mata tidur. Jom Faperta Universitas Riau 3(1): 1-10.

Dea T. 2009. Pengaruh dosis ekstrak rebung bambu betung (Dendrocalamus asper) terhadap perumbuhan semai sengon (Paraserianthes falcataria). Fakultas Kehutanan. IPB.

Direktorat Jenderal perkebunan. 2012. Daerah sumber tanaman pala di Propinsi Jawa Barat. Jakarta.

Astanu DA, Ismono H, Rosanti N. 2013. Analisis kelayakan finasial budidaya intensif tanaman pala di Kecamatan Gisting Kabupaten Tenggamus. JIIA 1 (3).

Kurniati F, Sudartini T, Permana D, 2015. Pengaruh konsentrasi berbagai jenis bahan zat pengatur tumbuh alami terhadap pertumbuhan bibit kemiri sunan (Reutealis Trisperma) (Blanco) Airy Shaw). Laporan Penelitian Hibah Penelitian Internal. LP2MPMP UNSIL.

Kurniati F, Sudartini T, Hidayat D. 2017. Aplikasi berbagai bahan ZPT alami untuk meningkatkan pertumbuhan bibit kemiri sunan (Reutealis trisperma (Blanco) Airy Shaw). Jurnal Agro 4(1): 40-49.

Kurniati F, Hodiyah I, Hartoyo T, Nurfalah I. 2018. Respons labu madu (Cucurbita moschata Durch) terhadap pemberian beberapa jenis bahan zat pengatur tumbuh berbagai dosis. Agrotech Res J 2(1): 16-21.

Frank B, Salisbury, Cleon W Ross. 1995. Plant Physiology. Penerjemah Diah Lukman dan Sumaryono. Fisiologi tumbuhan jilid 3 perkembangan tumbuhan dan fisiologi Lingkungan. Edisi 4. Penerbit ITB. Bandung

Franklin P. Gardner; R.Brent. Pearce dan Roger L. Mitchel. 2008. Fisiologi of Plant. Terjemahan Herawati Susilo dan Subiyanto. Fisiologi tanaman Budidaya.Universitas Indonesia Press. Jakarta.

Kwanchai A, Gomez, Arturo A Gomez. 2007. Prosedur Statistik untuk Penelitian Pertanian. Penerjemah Endang Sjamsudin,Justika S. Baharsjah. UIPress.Jakarta.

Lindung. 2014. Teknologi aplikasi zat pengatur tumbuh. balai pelatihan pertanian.Jambi. http://www.bppjambi.info/newspopup.asp?id=603. Diunduh.September 2017.

Mardaleni, Sutriana S. 2014. Pemberian ekstrak rebung dan pupuk hormon tanaman unggul terhadap pertumbuhan dan produksi kacang hijau (Vigna radiate L.). Jurnal Dinamika Pertanian. Volume XXIX Nomor 1: 45-56.

Maretza. 2009. Pengaruh dosis ekstrak rebung bambu betung terhadap pertumbuhan semai sengon
(Paraserianthes falcataria (L.). Institut Pertanian Bogor. Bogor.

Marfirani M, Rahayu YS, Ratnasari E. 2014.Pengaruh pemberian berbagai konsentrasi filtrat umbi bawang merah dan rootone $F$ terhadap pertumbuhan stek melati "RatoEbu". Jurnal on line Universitas Negeri Surabaya. Lentera Bio Volume 3(1): 73-76.

Nurlaeni Y, Surya MI. 2015. Respon stek pucuk camelia japonica terhadap pemberian zat pengatur tumbuh organik. Prosiding Seminar Nasional Masyarakat Biodiversity Indonesia I (5): 1211-1215

Isrianto PL. 2017. Pengaruh gibereline organik terhadap pertumbuhan tanaman keji beling. Jurnal Biologi dan Pembelajaran Biologi 2 (1): 23-37

Rismunandar. 1990. Budidaya dan tata niaga pala. Jakarta: PT. Penebar swadaya. Anggota IKAPI. Jakarta.

Rusmin D, Suwarno FC, Darwati I. 2011. Pengaruh pemberian GA3 pada berbagai konsentrasi dan lama imbibisi terhadap peningkatan viabilitas benih puwoceng (Pimpinella pruatjan Molk.). Jurnal Littri 17 (3): 89-94.

Septari Y, Nelvia, Amri Al. 2013. Pengaruh pemberian beberapa jenis ekstrak tanaman sebagai ZPT dan rasio amelioran terhadap varietas inpari 122 di lahan gambut. Jurnal on Line Mahasiswa. Fakultas Pertanian Universitas Riau 2(1):1-9

Siregar AP, Zuhry E, Sampoerno. 2015. Pertumbuhan bibit gaharu (Aquilaria malaccensis) dengan pemberian zat pengatur tumbuh asal bawang merah. Jurnal Online Mahasiswa. Fakultas Pertanian UniversitasRiau 2(1): 1-10.

Sudaryono T, Soleh M. 1994. Induksi akar pada perbanyakan salak secara vegetatif. Jurnal Penelitian Hortikultura 6 (2): 1-12.

Syahrul B. 2007. Prospek dan strategi pengembangan pala di Maluku. Persfektif 6 (2). Balai Pengkajian dan Pengembangan Teknologi Pertanian. Bogor (online); $\begin{array}{llll}\text { [diakses } & 2 & \text { Januari }\end{array}$ https://minyakatsiriindonesia.wordpress.com.

Wareing PF, Phillips IDJ. 1981. The Control of Growth and Differentiation in Plants.Pergamon Press. Ney York.

Wattimena GA. 2000. Diktat zat pengatur tumbuh tanaman. Laboratorium Kultur Jaringan. PAU Bioteknologi. IPB. Bogor

Widia L, Kojoh D, Runtunuwu S. 2017. Kajian budidaya tanaman pala (Myristica Fragrans Houtt.) di Kabupaten Kepulauan Sangihe. [Online]. Tersedia : https://ejournal.unsrat.ac.id/indexs.wuphp/cocos/arti cle/viewfile/14957/1452 9. [2 januari 2018].

Yenita. 2013. Pengaruh gibberellic acid (GA3) terhadap kacang tanah (Arachis hypogea) pada fase generatif. Seminar nasional XI pndidikan Biologi FKIP UNS. 